\title{
Improving Learning Outcomes of Residents Learning Packet C Through the Application of Tutor Teaching Skills
}

\author{
Yasaratodo Wau ${ }^{1}$, Fauzi Kurniawan ${ }^{2 *}$, Friska Indria Nora Harahap ${ }^{3}$, \\ Eka Puji Safitri ${ }^{4}$ Jubaidah Hasibuan ${ }^{5}$ \\ ${ }^{1-5)}$ Universitas Negeri Medan, Indonesia \\ *fauzi_k50@yahoo.com
}

\begin{abstract}
This study is Classroom Action Research, to determine increase learning in outcomes of citizens learning package $\mathrm{C}$. The study was conducted at PKBM Rizqi Ananda with 51 respondents. Result of study, there is increase of learning outcomes citizens learning package $\mathrm{C}$. The first cycle average value 73.86 with a cumulative achievement of the graduating class $60.78 \%$, while in the second cycle the average value 80 with grade passing $86.27 \%$. Data analysis by t-test showed a significant increase in learning outcomes of tutors' teaching skills. The first cycle with an average value of 71 while the second cycle of 87 is proven through the t test. The t test results showed a significant increase in the value of tutors' teaching skills. Thus there is an increase in learning outcomes of citizens learning package $C$ through the application of 8 tutors' teaching skills at PKBM Rizqy Ananda, Klambir Village Deli Serdang Regency
\end{abstract}

Keywords: teaching skills, learning outcomes, paket c

\section{Introduction}

Education is defined as a process of guiding, leading, and directing students with various problems or problems and questions that may arise in their implementation. Education is also interpreted as a process so that students can reach an optimal level of development in accordance with their personal potential so that humans become aware and responsible for the tasks of his life as a human being, in accordance with the nature and characteristics of humanity. Education as a process and as a result of its implementation requires a deep and comprehensive study so that the process of achieving the results can improve human dignity and dignity as a noble human being.

Efforts to improve the quality of human resources through non-formal education channels (non-school education) can be pursued through equality education which includes paket $\mathrm{A}$, paket $\mathrm{B}$, and paket $\mathrm{C}$ which aims to provide opportunities for citizens to attend quality primary and secondary education and relevant to the needs of students who do not have the opportunity to learn in formal education. Increased attention and community participation in the paket A and paket B programs need to be balanced with efforts to prepare students' competencies in order to have readiness to enter the community and the world of work, because most of them do not continue to a higher level.

Based on the results of interviews with PKBM owner Rizqy Ananda that paket A program diplomas have the same eligibility rights as SD / MI certificate holders, paket B programs have the same eligibility rights as SMP / MTs diploma holders, paket C programs have the same eligibility rights with high school / MA diploma holders. From the results of 
observations note that the learning outcomes of citizens learning paket $\mathrm{C}$ are relatively low. This can be seen in the learning outcomes of paket $\mathrm{C}$ learning citizens after observing on January 7, 2019, when interviewing PKBM owner Rizqi Ananda who said the daily test scores obtained by paket $\mathrm{C}$ learning citizens in Indonesian subjects were still incompatible with the Criteria value The minimum completeness (KKM) that has been set is $\geq 70$.

Table 1. Daily Indonesian Test scores in Odd Semesters of Residents

\begin{tabular}{cccccl}
\hline Year & Value & Category & amount & Percent (\%) & Information \\
\hline \multirow{2}{*}{$2018 / 2019$} & $90-100$ & A & - & - & Very competent \\
& $70-79$ & B & 19 & 37.25 & Competent \\
& $<70$ & $\mathrm{C}$ & 9 & 17.65 & Quite competent \\
\hline amount & & $\mathrm{D}$ & 23 & 45.10 & Incompetent \\
\hline
\end{tabular}

Source: PKBM Rizqi Ananda

The low learning outcomes of citizens paket $\mathrm{C}$ learning in Rizqi Ananda PKBM caused by many factors namely: Lack of interest in learning in participating in the learning process, lack of attention of citizens learning when tutors explain learning material, lack of motivation of learning in participating in the learning process, and awareness of learning citizens in follow the teaching and learning process is not optimal, and the lack of tutor teaching skills, namely the skills to open and close lessons, the skills to explain, the skills to ask questions, the skills to provide reinforcement, and the skills to use learning media. This is consistent with the statement of Gina (2016) that in reality the problem that arises in the teaching and learning process is the low student learning outcomes. The low student achievement is caused by low student understanding which is caused by the teaching and learning process that is less effective. A tutor should have skills in teaching, the success of the learning process at school is also determined by several important factors, namely tutors, learning citizens, and the availability of learning facilities and infrastructure. [1]

Tutor teaching skills are one type of skills that tutors must master. By having teaching skills, tutors can manage the learning process properly which has implications for the learning outcomes of learning citizens. Tutor teaching skills are skills that absolutely must be possessed by a tutor. In the learning process is inseparable from the role of the tutor. The learning process will achieve the desired results if the tutor has good teaching skills and learning citizens have an interest in accepting the lessons given by the tutor. Having skills in teaching is expected to improve the learning outcomes of citizens learning. [2]

The results of observations made by the author on the implementation of teaching and learning activities paket $\mathrm{C}$ program at PKBM Rizqy Ananda, the tutor has not used eight teaching skills, namely: (1) opening and closing lessons, (2) explaining skills, (3) questioning skills (4) strengthening skills, (5) classroom management skills, (6) variation skills, (7) individual teaching skills in small groups, (8) small group discussion skills. But only using three teaching skills, namely opening and closing skills, explaining skills, and questioning skills.

From the information delivered directly by one of the tutors at PKBM Rizqi Ananda, the reason the tutor had not applied the eight teaching skills was because he had not mastered them and was accustomed to only using open and close skills, explaining skills, and questioning skills. Tutors only focus on these three skills. Other information obtained from interviews from PKBM owner Rizqi Ananda is the lack of awareness of citizens learning to 
attend the teaching and learning process also becomes a barrier for tutors to maximize learning. This is the reason why learning outcomes of learning citizens are still below 50 . Learning residents still think that they prefer to work to help the family economy is one of the reasons for not participating in learning activities. There are also those who argue that the distance from home to the location of learning activities is quite far and the weather is hot so that the desire to come to participate in learning activities is reduced.

Therefore, tutor skills are very necessary for the continuity of a pleasant learning process, which is able to foster the willingness of citizens to learn to learn, and always create pleasant classroom conditions as well as learning citizens must also be aware of the importance of education. The extent to which teaching skills can improve learning outcomes of paket $\mathrm{C}$ learners needs to be reviewed and conducted research with the title Improvement of Learning Outcomes of Learning paket $\mathrm{C}$ through the Implementation of 8 Teaching Skills in PKBM Rizqy Ananda Hamlet V, Klambir Village, Hamparan Perak District, Deli Serdang Regency.

\section{Research Method}

This type of research used in this study is Classroom Action Research (PTK). In this study, the subjects of the study were citizens learning paket $\mathrm{C}$ in Rizqi Ananda PKBM with a total of 51 learning residents. In this study there were 2 (two) variables of concern to be examined, namely: Dependent variable (Y) was the result of citizen learning learning package $\mathrm{C}$ in PKBM Rizqi Ananda and the independent variable (X) in this study was the application of 8 tutors' teaching skills. The Classroom Action Research (PTK) procedure starts with the first cycle consisting of four activities, namely planning, acting, observing, and reflecting.If the researcher already knows the location of the successes and obstacles of the action carried out in the first cycle, the researcher determines the design of the following actions in the second cycle. In the second cycle has various additions to the improvement of the obstacles and difficulties found in the first cycle of action, if the researcher is not satisfied with the improvement and improvement of these actions, the researcher can continue the third cycle as described as follows: [3]

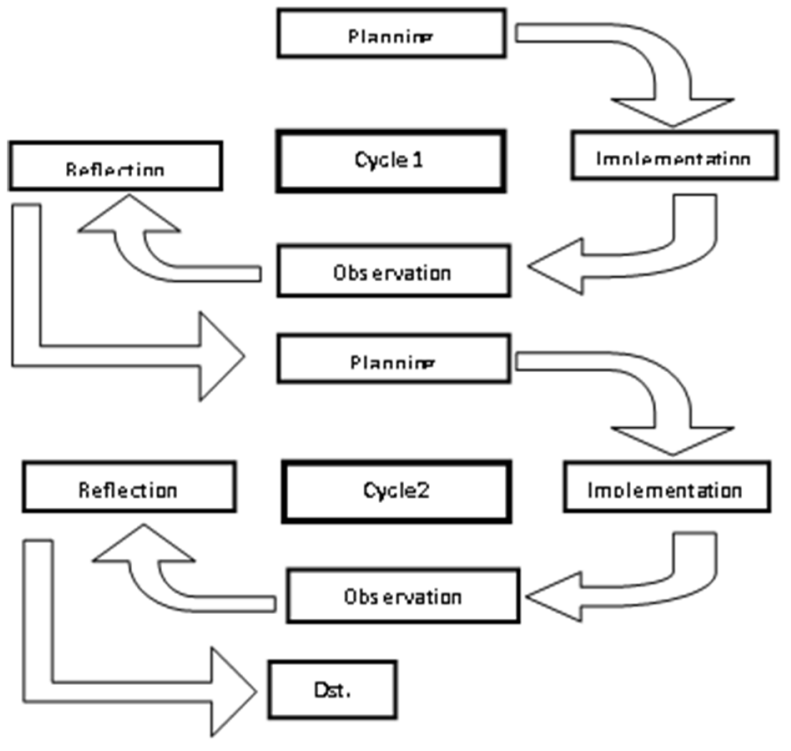

Figure 1. Classroom Action Research Cycle 


\section{Results and Discussion}

The results of achieving improved learning outcomes through the application of 8 Tutor teaching skills can improve learning outcomes. The following graph is the comparison of learning outcomes:

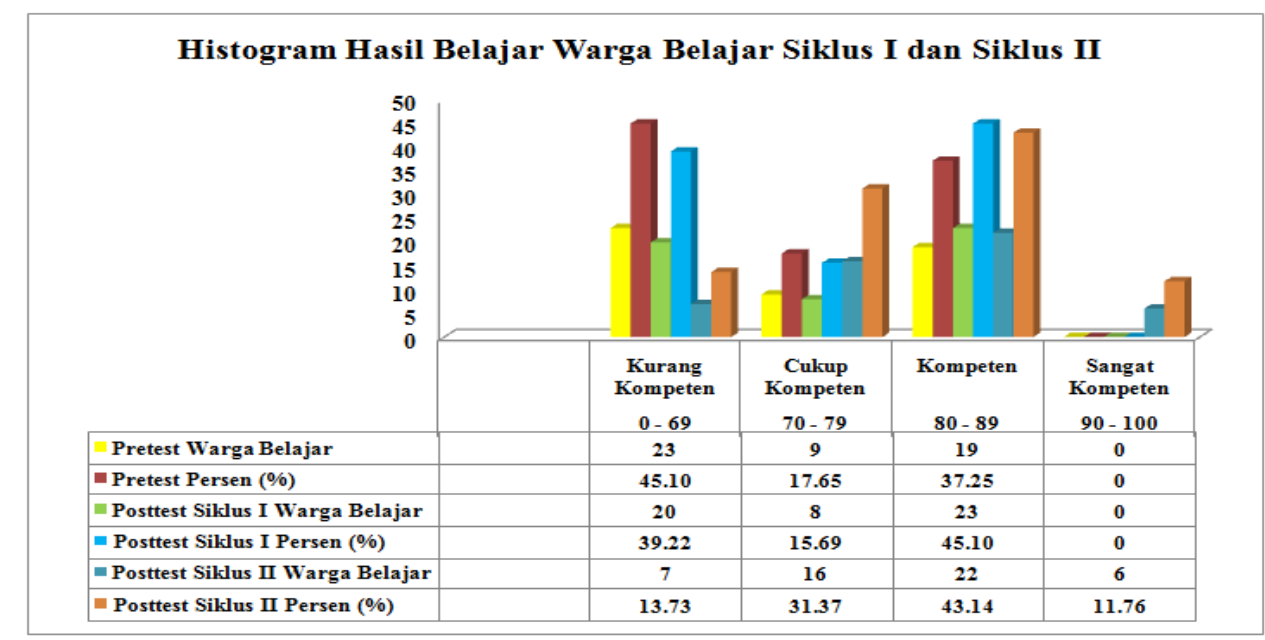

Figure 2. Histogram Learning Cycle I and Cycle II

From the results of the learning outcomes of the pretest learning citizens it was obtained 23 learning residents in the category of less competent with a percentage of $45.10 \%$ and 9 learning residents in the category of quite competent with a percentage of $17.65 \%$ and 19 residents learning in the competent category with a percentage of $37.25 \%$ and the average grade of 67.20 with a cumulative grade of graduation $54.90 \%$, while in the first cycle above, it is known that 20 residents learn in the category of less competent with a percentage of $39.22 \%$ and 8 residents learn in the category of quite competent with a percentage of $15,69 \%$ and 23 residents learned in the competent category with a percentage of $45.10 \%$ and the average value of the class reached 73.86 with a cumulative grade of graduating $60.78 \%$.

From these results we can see that the learning outcomes of the learning community are still low because the tutor has not yet applied his teaching skills to the maximum and also the tutor is not sure of his ability when transferring knowledge in the sense of not being wholeheartedly, and the low willingness of the learning community to follow the teaching and learning process. This is in accordance with Darmadi's opinion, teaching is an art to transfer knowledge, skills and values that are directed by the values of education, individual needs of citizens to learn, environmental conditions, and beliefs owned by tutors. [4]

In the second cycle it is known that there are only 7 people learning in the category of less competent with a percentage of $13.73 \%, 16$ learning people in the category of quite competent with a percentage of $31.37 \%$ and 22 learning citizens in the category of competent with a percentage of $43.14 \%$ while in the category very competent, there are 6 students with a percentage of $11.76 \%$, this shows that an increase in learning outcomes in the second cycle with an average grade of 80 reached with $86.27 \%$ graduating grade achievement. The complete data is presented in appendix 6 . The increase in learning outcomes that occur is still not maximal due to the tutor's unfamiliarity in using the teaching skills, so to maximize the 
value of learning outcomes continued into the second cycle. This is consistent with the opinion of Isra that tutor teaching skills have a close relationship with learning outcomes of learning citizens. [5]

Thus based on this analysis it can be stated that the Application of 8 Tutor Teaching Skills can Improve Learning Outcomes of Learning Community Package C in PKBM Rizqi Ananda. This is in accordance with the opinion of Aunurrahman who stated that learning outcomes are marked by changes in behavior. The intended behavior is that there is a change in the value of the Kurag from good to good because the tutor and the learning community are in line. [6] Just as learning outcomes of learning citizens after the implementation of the action showed that a significant increase was also evidenced through the $t$ test. The $t$ test results showed a significant increase in learning outcomes ie obtained $t$ count (10.23)>t table (2.010) with the level significant $5 \%$.

From the simple correlation calculation using the Product Moment method in Appendix 11, the correlation coefficient between $\mathrm{X}$ and $\mathrm{Y}=24,489$; while $\mathrm{r}_{\mathrm{t}}$ with $\mathrm{N}=51$ and a significance level of $5 \%$ is 0.272 . Thus the price of $r$ count $>r$ table $(24.489>0.272)$ so that the correlation coefficient of the variable $\mathrm{X}$ to the $\mathrm{Y}$ variable is significant. Furthermore, the significance of the correlation test using the t-test was obtained tcount of 7.004. For the price of table with $\mathrm{dk}=49$ is 1.677 , it looks tc $>$ tt, i.e. (7.004>1.677), with criteria for acceptance and rejection of the hypothesis, the proposed working hypothesis (Ha) is accepted at a significance level of 5\%. Thus it is stated that there is a significant correlation between 8 Tutor Teaching Skills (X) to Learning Outcomes Learning Outcomes (Y) Package C at PKBM Rizqi Ananda Deli Serdang Regency.

\section{Conclusion}

Based on the results of classroom action research (CAR) it can be concluded as follows:

1) There is an increase in the value of learning outcomes of citizens learning package $C$, cycle I the average value of the class reached 73.86 with a cumulative grade of graduation $60.78 \%$, while in cycle I the average value of the class reached 80 with the grade achievement pass $86.27 \%$. The results of the t test showed a significant increase in learning outcomes ie obtained $t$ count (10.23)> $t$ table (2.010) with a significant level of $5 \%$.

2) There is an increase in the value of tutor teaching skills, the first cycle with an average value of 71 while the second cycle of 87 is evidenced through the $t$ test. The $t$ test results showed a significant increase in the value of tutors' teaching skills, obtained by $t$ arithmetic (7.76) $>\mathrm{t}$ table $(2,365)$ with a significant level of $5 \%$.

3) There is an increase in learning outcomes of citizens learning package $C$ which means through the application of 8 tutors' teaching skills with a correlation value of $r_{\text {count }}>r_{\text {table }}$ $(29,259>0,272) t_{\text {test }}>t_{\text {table }}(8,369>1,677)$.

\section{References}

[1] Aunurrahman. (2012), Belajar dan Pembelajaran. Bandung: Alfabeta.

[2] Darmadi, H. (2012), Kemampuan Dasar Mengajar. Bandung: Alfabeta.

[3] Febriani, I. (2018), Pengaruh Keterampilan Mengajar Guru Terhadap Minat Belajar Siswa Di MTS Aswaja Tunggangri Tulungagung, Jurnal. IAIN Tulungagung. 
[4] Gina, F. (2017), Pengaruh Keterampilan Mengajar Guru Terhadap Prestasi Belajar Siswa Pada Mata Pelajaran Ekonomi Kelas XI IPS Di SMA Pasundan 3 Bandung, Jurnal.Universitas Pasundan. Bandung.

[5] Iskandar. (2012), Penelitian Tindakan Kelas. Jakarta:Referensi.

[6] Isra, Z. (2012), Hubungan Keterampilan Mengajar Tutor Dengan Hasil Belajar Warga Belajar Paket B Di SKB Asahan.Unimed. Medan.

[7] Sugiyono. (2009), Metode Penelitian Kuantitatif Kualitatif Dan $R \&$ D Edisi Revisi. Bandung: Alfabeta. 